\title{
STRATEGI PERENCANAAN PENGEMBANGAN PARIWISATA UNTUK MEWUJUDKAN DESTINASI TANGGUH BENCANA DI WILAYAH KEPESISIRAN DRINI GUNUNGKIDUL
}

\author{
Muhammad Rizal Pahleviannur', Diyah Ayu Wulandari², Salma Lutfiani \\ Sochiba $^{3}$, Ramadhini Rudi Santoso ${ }^{4}$ \\ 1,2,3,4Pendidikan Geografi, Universitas Muhammadiyah Surakarta \\ e-mail: pahlevi.geoedu@gmail.com
}

\begin{abstract}
The coastal region in Indonesia is one of the densest areas of settlement and development, even some of the major cities in Indonesia located in the coastel area and become a major tourism destination. However, behind the beauty there is a threat in the form of natural disasters, if the management of tourism is not optimal for facilities and infrastructure can increase the risk of disaster. This study aims to recommend planning for disaster based tourism development with structural mitigation. This research is a qualitative research. The data collection method used in this research is to conduct literature studies, observations, and documentation. The result of this study indicate that the facilities and infrastructure available at Drini Beach are classified as incomplete in terms of structural mitigation against disaster, so there is a need for planning in developing disaster resilient tourism, with the aim of creating a friendly an resilient tourism climate.
\end{abstract}

Keywords: drini beach, disaster resilient tourism, mitigation

\section{PENDAHULUAN}

Pariwisata merupakan keseluruhan kegiatan yang berhubungan dengan masuk, tinggal, dan pergerakan penduduk asing di dalam atau di luar suatu negara, kota, atau wilayah tertentu (Muljadi \& Nurhayati, 2002). Indonesia adalah negara yang memiliki sumberdaya alam yang melimpah, kekayaan seni budaya, adat istiadat, peninggalan sejarah, sehingga hal tersebut merupakan potensi yang dapat dikembangkan dalam sektor pariwisata (Primadany, 2013). Potensi wisata Indonesia yang memiliki kurang lebih 17.508 pulau dengan garis pantai sepanjang $81.000 \mathrm{~km}$ dan luas sekitar 3,1 juta $\mathrm{km}^{2}$ menyimpan sumberdaya potensial (Dahuri, Rais, Ginting, \& Sitepu, 2001). Namun, di balik potensi dan daya tarik yang dimiliki Indonesia pada sektor pariwisata, letak Indonesia menyimpan ancaman dan bahaya yang dapat membahayakan.

Negara Indonesia terdiri atas gugusan pulau yang terletak di antara dua benua dan dua samudera, serta berada pada tiga pertemuan lempeng aktif, IndoAustralia, Eurasia, dan Pasifik, sehingga menyebabkan terjadinya dinamika kondisi alam yang dapat memicu terjadinya bencana alam (Lasabuda, 2013). Bencana alam yang berpotensi terjadi di wilayah pesisir dengan ancaman bahaya tinggi yaitu gempa dan tsunami. Gempa bumi merupakan getaran atau guncangan yang terjadi di permukaan bumi karena adanya tumbukan antar lempeng bumi, patahan aktif, aktivitas gunungapi, dan runtuhan batuan (Rijanta, Hizbaron, \& Baiquni, 2018), sedangkan tsunami merupakan gelombang panjang yang mengakibatkan 
kerusakan dahsyat jika menghantam pantai atau pesisir (Maghfiroh Asti, 2014). Menyadari dengan adanya risiko bencana yang terdapat di Indonesia, penting untuk mendorong kesadaran terhadap bencana terutama di wilayah pesisir, sehingga risiko terjadinya bencana tersebut dapat dikurangi.

Pesisir merupakan wilayah multifungsi, seperti pusat pemerintahan, permukiman, industri, pelabuhan, pertambakan, pertanian, dan pariwisata. Wilayah pesisir yang memiliki multifungsi tersebut mengakibatkan peningkatan kebutuhan dan penggunaan lahan, sehingga dapat menimbulkan permasalahan baru di wilayah pesisir, seperti perubahan morfologi yang tentu saja dapat membahayakan (Westplat, Tondobala, \& Makarau, 2017). Kabupaten Gunungkidul merupakan salah satu kabupaten yang memiliki sektor unggulan wisata alam di kawasan pantai. Kabupaten Gunungkidul memiliki garis pantai sepanjang $65 \mathrm{~km}$ dengan pantai yang banyak mendapat perhatian wisatawan adalah Pantai Baron, Kukup, Sepanjang, Drini, Krakal, dan Sadranan. Pantai Drini merupakan salah satu pantai yang memiliki potensi alam pasir putih, pulau karang, dan biota laut yang cukup lengkap (Damayanti \& Ayuningtyas, 2008). Namun, di balik keindahan tersebut terdapat ancaman berupa bencana alam, jika pengelolaan pariwisata tersebut tidak optimal terhadap sarana dan prasarana dapat meningkatkan risiko terjadinya bencana.

Undang-undang Nomor 24 Tahun 2007 tentang Penyelenggaraan Penanggulangan Bencana, dapat dijelakan bahwa penanggulangan bencana merupakan serangkaian upaya yang dilakukan untuk mengurangi dampak yang ditimbulkan dari kejadian bencana dengan cara pencegahan, tanggap darurat, dan rehabilitasi. Secara umum, manajemen bencana dibagi dalam tiga kegiatan, yaitu pertama kegiatan pra-bencana (pencegahan, mitigasi, kesiapsiagaan, dan peringatan dini). Kedua, saat terjadi bencana (tanggap darurat, bantuan darurat, dan pengungsian). Ketiga, pasca bencana (pemulihan, rehabilitasi, dan rekonstruksi) (Wicaksono \& Pangestuti, 2019). Kegiatan pra-bencana erat kaitannya dengan mitigasi bencana yang merupakan upaya untuk meminimalisasi dampak dari bencana.

Berdasarkan Peraturan Menteri Dalam Negeri No. 33 Tahun 2006 tentang Pedoman Umum Mitigasi Bencana, kegiatan mitigasi bencana dilaksanakan dengan tujuan untuk mengetahui potensi bencana dan melakukan upaya antisipasi penanganannya. Pengurangan risiko melalui mitigasi dilakukan sebelum bencana terjadi, sehingga masyarakat dapat meminimalisasi risiko terhadap terjadinya bencana. Mitigasi dapat dikelompokkan menjadi dua, yaitu mitigasi struktural dan mitigasi non struktural. Mitigasi struktural merupakan upaya secara fisik yang dilakukan untuk mengurangi dampak yang ditimbulkan dari kejadian bencana, seperti pembangunan infrastruktur dan penggunaan teknologi, sedangkan mitigasi non struktural merupakan tindakan yang terkait dengan kebijakan, pengembangan pengetahuan, termasuk di antaranya peningkatan kapasitas masyarakat terhadap bencana (Rahman, 2015).

Wilayah pesisir di Indonesia merupakan salah satu wilayah yang padat terhadap permukiman dan pembangunan, bahkan beberapa kota besar yang terdapat di Indonesia terletak di daerah pesisir dan menjadi tujuan utama pariwisata. Berkaitan dengan pariwisata, dalam upaya mewujudkan pariwisata tangguh bencana, perlu adanya perencanaan pengembangan pariwisata menuju 
destinasi tangguh bencana dengan menerapkan mitigasi pada destinasi wisata tersebut. Kondisi demikian menunjukkan bahwa adanya mitigasi perlu untuk mewujudkan pariwisata tangguh bencana di Wilayah Kepesisiran Drini Gunungkidul.

\section{METODE PENELITIAN}

Penelitian ini merupakan penelitian kualitatif. Metode pengumpulan data yang dilakukan dalam penelitian ini adalah dengan melakukan studi literatur, observasi, dan dokumentasi. Komponen yang diamati adalah enam komponen pengembangan pariwisata yang terdiri dari daya tarik (attractions), aksesibilitas (accessibility), amenitas (amenities), ketersediaan paket wisata (available packages), aktivitas (activities), dan layanan tambahan (ancillary services). Kemudian, analisis terhadap kerentanan wilayah dan perencanaan pengembangan pariwisata tangguh bencana. Cara penyajian data yang dilakukan dalam penelitian ini secara deskriptif, dengan tujuan untuk mendeskripsikan fenomena atau kejadian yang berlangsung di lapangan.

\section{HASIL DAN PEMBAHASAN}

\section{Analisis Faktor Attractions, Accessibility, Amenities, Available Packages,} Activities, Ancillary Services (6A)

\section{a. Attractions}

Hampir setiap kawasan wisata memiliki atraksi tersendiri untuk menarik wisatawan berkunjung, salah satu destinasi wisata tersebut adalah Pantai Drini. Atraksi yang paling utama terdapat di Pantai Drini adalah panorama alam yang berupa pantai. Selain memiliki panorama alam, Pantai Drini juga memiliki daya tarik lain yang dapat menjadikan wisatawan untuk mengunjungi destinasi, seperti taman, gardu pandang, wisata belanja, wisata kuliner, dan lain-lain. Dengan adanya daya tarik yang cukup lengkap, dapat menjadikan suatu destinasi wisata tersebut menjadi nyaman untuk dikunjungi oleh wisatawan.

Tabel 1.

Atraksi di Pantai Drini

\begin{tabular}{ccc}
\hline No & Atraksi & Pantai Drini \\
\hline 1. & Panorama alam (pantai) & $\sqrt{ }$ \\
2. & Daya tarik buatan (taman/gardu pandang) & $\sqrt{ }$ \\
3. & Upacara adat/tradisional/event musiman & - \\
4. & Wisata belanja & $\sqrt{ }$ \\
5. & Wisata kuliner & $\sqrt{ }$ \\
\hline
\end{tabular}

Sumber: Data Hasil Penelitian yang Diolah

Berikut hasil dokumentasi daya tarik yang terdapat di Pantai Drini.

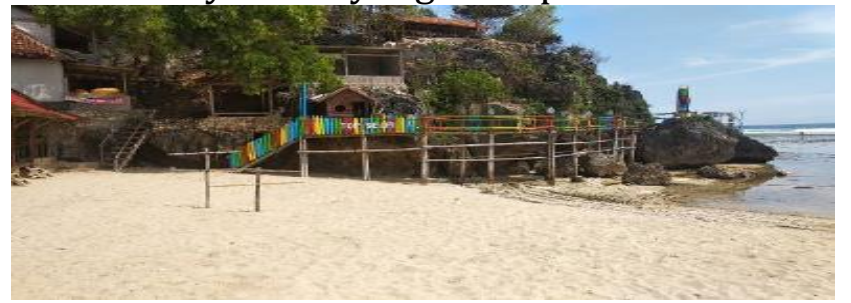

Gambar 1.

Atraksi di Pantai Drini

Sumber: Data Hasil Penelitian yang Diolah

Jurnal Pendidikan IImu Sosial, Vol 29, No.2, Desember 2019, 


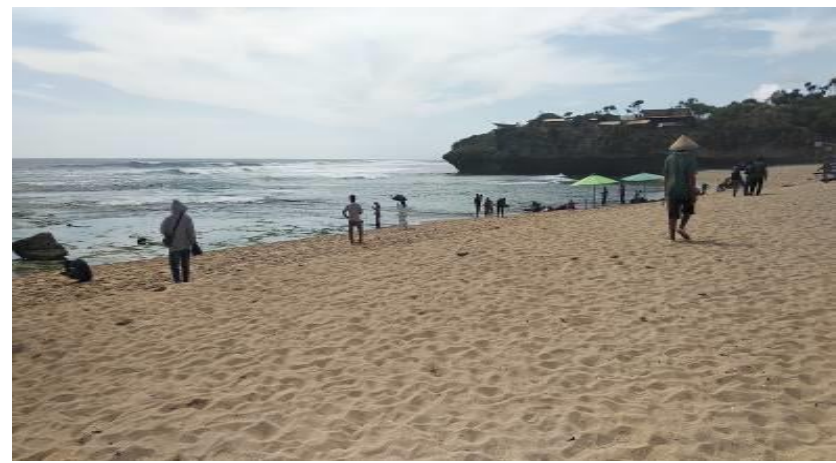

Gambar 2.

Atraksi di Pantai Drini

Sumber: Data Hasil Penelitian yang Diolah

\section{b. Accessibility}

Aksesibilitas untuk menuju Pantai Drini tingkat kemudahannya sedang, dengan tipe jalan aspal, dan moda transportasi darat yang dapat melalui jalan tersebut cukup beragam, seperti dapat dilalui oleh transportasi roda dua, roda empat, dan sebagainya. Dengan kondisi aksesibilitas seperti itu, dapat memudahkan bagi wisatawan untuk mengunjungi destinasi tersebut, sehingga tidak mengalami kesusahan dalam menjangkau Pantai Drini tersebut.

Tabel 2.

Aksesibilitas di Pantai Drini

\begin{tabular}{cccc}
\hline No & Aksesibilitas & Jenis & Pantai Drini \\
\hline 1. & Kemudahan & Mudah & - \\
& & Sedang & $\sqrt{ }$ \\
& & Sulit & - \\
2. & Tipe jalan & Aspal & $\sqrt{ }$ \\
& & Batu & - \\
& & Tanah & - \\
3. & Moda transportasi darat & Roda 2 & $\sqrt{ }$ \\
& & Roda 4 & $\sqrt{ }$ \\
& & >Roda 4 & $\sqrt{ }$ \\
\hline
\end{tabular}

Sumber: Data Hasil Penelitian yang Diolah

\section{c. Amenities}

Amenitas yang terdapat di Pantai Drini sangat beragam dengan adanya tempat ibadah dan penginapan seperti masjid/mushola/surau, homestay, dan losmen. Dalam hal catering, terdapat rumah makan dan warung makan. Kemudian, retail yang terdapat di Pantai Drini seperti toko makanan khas (oleh-oleh), toko cindera mata, toko kelontong, dan lain-lain. Adanya amenitas tersebut dapat memberikan kenyamanan bagi wisatawan jika ingin melakukan ibadah dan bermalam di sekitar Pantai Drini. Lalu, juga terdapat rumah makan, warung makan dan terdapat toko retail yang bertujuan untuk memberikan bingkisan terhadap keluarga, seperti cindera mata dan oleh-oleh. 
Tabel 3.

Amenitas di Pantai Drini

\begin{tabular}{|c|c|c|c|}
\hline No & Amenitas & Jenis & Pantai Drini \\
\hline \multirow[t]{5}{*}{1.} & $\begin{array}{c}\text { Tempat ibadah dan } \\
\text { penginapan }\end{array}$ & Masjid/mushola/surau & $\sqrt{ }$ \\
\hline & & Hotel & - \\
\hline & & Vila & - \\
\hline & & Homestay & $\sqrt{ }$ \\
\hline & & Losmen & $\sqrt{ }$ \\
\hline \multirow[t]{4}{*}{2.} & Catering & Restoran & - \\
\hline & & Rumah makan & $\sqrt{ }$ \\
\hline & & Warung makan & $\sqrt{ }$ \\
\hline & & Cafe/snack bar & - \\
\hline \multirow[t]{3}{*}{3.} & Retail & $\begin{array}{l}\text { Toko makanan khas } \\
\text { (oleh-oleh) }\end{array}$ & $\sqrt{ }$ \\
\hline & & Toko cindera mata & $\sqrt{ }$ \\
\hline & & Toko kelontong & $\sqrt{ }$ \\
\hline
\end{tabular}

Sumber: Data Hasil Penelitian yang Diolah

Berikut hasil dokumentasi amenitas yang terdapat di Pantai Drini.

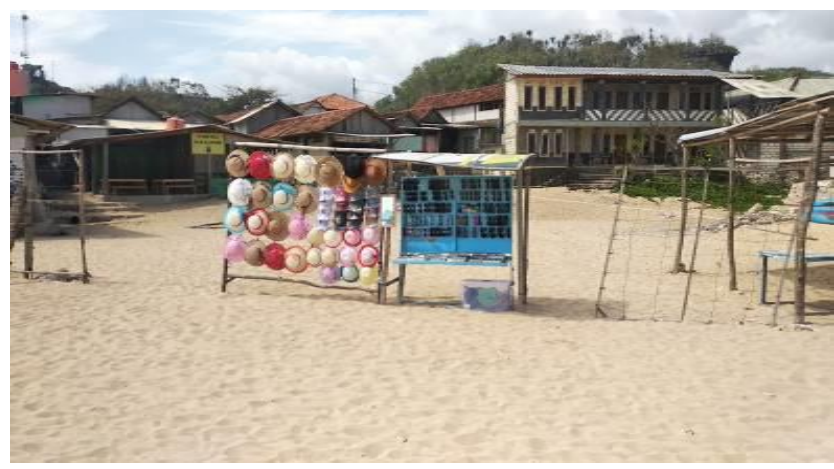

Gambar 3.

Amenitas di Pantai Drini

Sumber: Data Hasil Penelitian yang Diolah

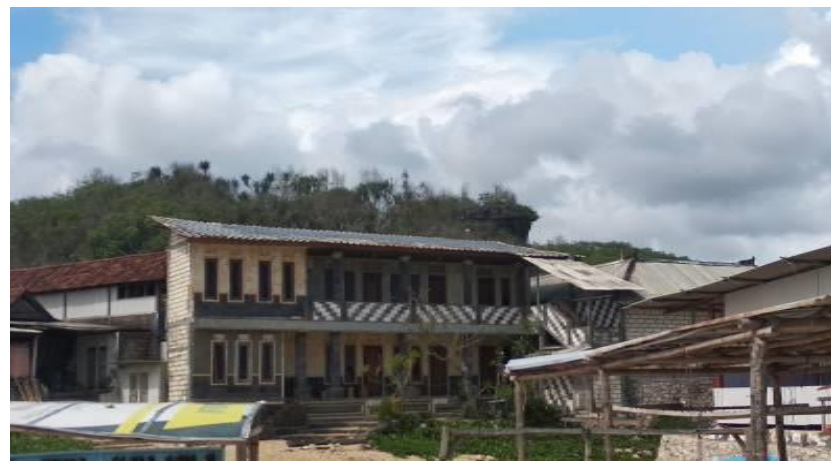

Gambar 4.

Amenitas di Pantai Drini

Sumber: Data Hasil Penelitian yang Diolah 


\section{d. Available Packages}

Ketersediaan paket wisata yang terdapat di Pantai Drini seperti paket tour dari biro perjalanan atau travel, paket wisata lokal di objek tertentu, paket wisata dengan objek di sekitarnya, paket kunjungan wisata dan aktivitas wisata.

Tabel 4.

Ketersediaan Paket Wisata di Pantai Drini

\begin{tabular}{ccc}
\hline No & Ketersediaan Paket Wisata & Pantai Drini \\
\hline 1. & Paket tour dari biro perjalanan/travel & $\sqrt{ }$ \\
2. & Paket wisata lokal di objek tertentu & $\sqrt{ }$ \\
3. & Paket wisata dengan objek di sekitarnya & $\sqrt{ }$ \\
4. & Paket kunjungan wisata dan aktivitas wisata & $\sqrt{ }$ \\
\hline Sumber: & Data Hasil Penelitian yang Diolah
\end{tabular}

Sumber: Data Hasil Penelitian yang Diolah

\section{e. Activities}

Aktivitas yang dilakukan oleh wisatawan dapat ditunjang oleh beberapa sarana dan prasarana, seperti photo spot, kendaraan air (perahu, banana boat, dll), memancing, camping ground, dan sebagainya. Aktivitas tersebut memiliki nilai tersendiri yang dapat menunjang destinasi wisata yang terdapat di Pantai Drini.

Tabel 5.

Aktivitas di Pantai Drini

\begin{tabular}{ccc}
\hline No & Aktivitas & Pantai Drini \\
\hline 1. & Renang/Diving/Snorkeling & - \\
2. & Photo spot & $\sqrt{ }$ \\
3. & Kendaraan air (perahu, banana boat, dll) & $\sqrt{ }$ \\
4. & Memancing & $\sqrt{ }$ \\
5. & Outbound/paintball & - \\
6. & Camping ground & $\sqrt{ }$ \\
\hline
\end{tabular}

Sumber: Data Hasil Penelitian yang Diolah

Berikut hasil dokumentasi aktivitas yang terdapat di Pantai Drini.

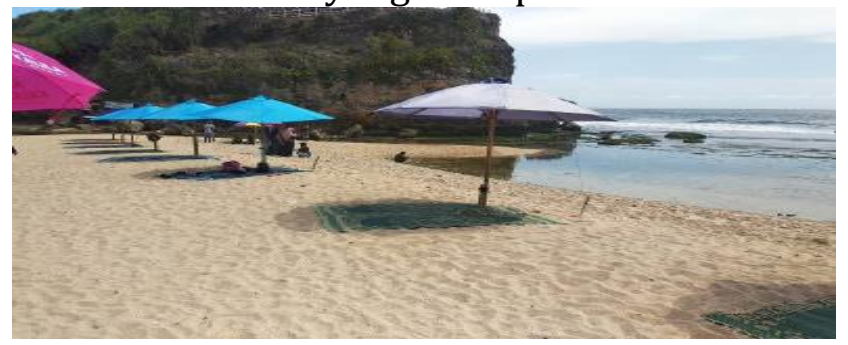

Gambar 5.

Aktivitas di Pantai Drini

Sumber: Data Hasil Penelitian yang Diolah

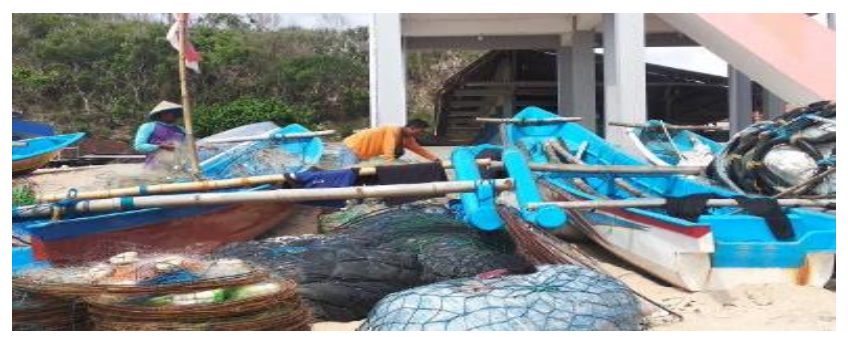

Gambar 6.

Aktivitas di Pantai Drini

Sumber: Data Hasil Penelitian yang Diolah 


\section{f. Ancillary Services}

Ancillary services yang terdapat di Pantai Drini yaitu pos penjaga pantai dan tempat parkir. Kedua hal tersebut memiliki manfaat tersendiri dalam menunjang destinasi wisata di Pantai Drini. Adanya pos penjaga pantai dapat menunjukkan bahwa pengelola tempat wisata memiliki keseriusan dalam menjaga para wisatawan agar selalu terpantau keselamatannya, sedangkan tempat parkir dapat menunjang wisatawan yang membawa kendaraan besar untuk bisa parkir di tempat yang luas dan mudah.

Tabel 6.

Ancillary Services di Pantai Drini

\begin{tabular}{ccc}
\hline No & Ancillary Services & Pantai Drini \\
\hline 1. & Bank & - \\
2. & Kantor pos & - \\
3. & Pasar & - \\
4. & Telepon umum & - \\
5. & Rumah sakit & - \\
6. & Puskesmas/klinik/praktik dokter & - \\
7. & Apotek & - \\
8. & Pos penjaga pantai & $\sqrt{ }$ \\
9. & Tempat parkir & $\sqrt{ }$ \\
\hline
\end{tabular}

Sumber: Data Hasil Penelitian yang Diolah

Berikut hasil dokumentasi ancillary services yang terdapat di Pantai Drini.

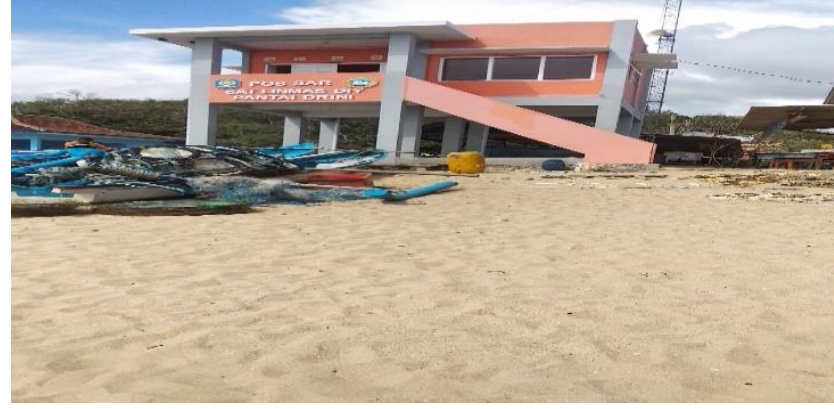

Gambar 7.

Ancillary Services di Pantai Drini

Sumber: Data Hasil Penelitian yang Diolah

\section{Analisis Kerentanan Wilayah}

Dalam hal ini terdapat rencana adaptasi secara struktural dengan tujuan untuk meningkatkan kesiapsiagaan wilayah terhadap bencana yang dirangkum dalam tabel sebagai berikut.

Tabel 7.

Kesiapsiagaan Wilayah Terhadap Bencana di Pantai Drini

\begin{tabular}{cccc}
\hline No & $\begin{array}{c}\text { Kesiapsiagaan Wilayah } \\
\text { Terhadap Bencana }\end{array}$ & Jenis & Pantai Drini \\
\hline 1. & Tanda evakuasi & Peringatan/rambu/tanda & $\sqrt{ }$ \\
& bahaya & \\
& & $\begin{array}{c}\text { Peringatan/rambu/tanda } \\
\text { titik kumpul }\end{array}$ & \\
& Jalur evakuasi & - \\
& Titik kumpul & - \\
& Pos penjaga & $\sqrt{ }$ \\
\hline
\end{tabular}




\begin{tabular}{|c|c|c|c|}
\hline No & $\begin{array}{l}\text { Kesiapsiagaan Wilayah } \\
\text { Terhadap Bencana }\end{array}$ & Jenis & Pantai Drini \\
\hline \multirow{6}{*}{2.} & \multirow{6}{*}{$\begin{array}{l}\text { Bentuk bangunan (rumah, } \\
\text { hotel, toko, dll) }\end{array}$} & pantai/SAR/BPBD & \\
\hline & & Pengeras suara & $\sqrt{ }$ \\
\hline & & Early Warning System & - \\
\hline & & 1 lantai & $\sqrt{ }$ \\
\hline & & 2 lantai & $\sqrt{ }$ \\
\hline & & $>2$ lantai & - \\
\hline \multirow[t]{3}{*}{3.} & \multirow[t]{2}{*}{ Kondisi jalur evakuasi } & Buruk & - \\
\hline & & Sedang & $\sqrt{ }$ \\
\hline & \multirow{4}{*}{ Kondisi titik kumpul } & Baik & - \\
\hline \multirow[t]{3}{*}{4.} & & Buruk & - \\
\hline & & Sedang & $\sqrt{ }$ \\
\hline & & Baik & - \\
\hline
\end{tabular}

Sumber: Data Hasil Penelitian yang Diolah

Terdapat beberapa adaptasi secara struktural yang terdapat di Pantai Drini, seperti tanda evakuasi (peringatan/rambu/tanda bahaya, pos penjaga pantai/SAR/BPBD, pengeras suara, dan early warning system), bentuk bangunan (rumah, hotel, toko, dll) terdiri 1-2 lantai, kondisi jalur evakuasi sedang, dan kondisi titik kumpul sedang. Dalam analisis kerentanan wilayah, adanya tanda evakuasi, jalur evakuasi, dan titik kumpul dapat dinyatakan bahwa wilayah tersebut sudah menerapkan upaya mitigasi secara struktural yang bertujuan untuk meminimalisasi dampak terjadinya suatu bencana. Berikut hasil dokumentasi analisis kerentanan wilayah yang terdapat di Pantai Drini.

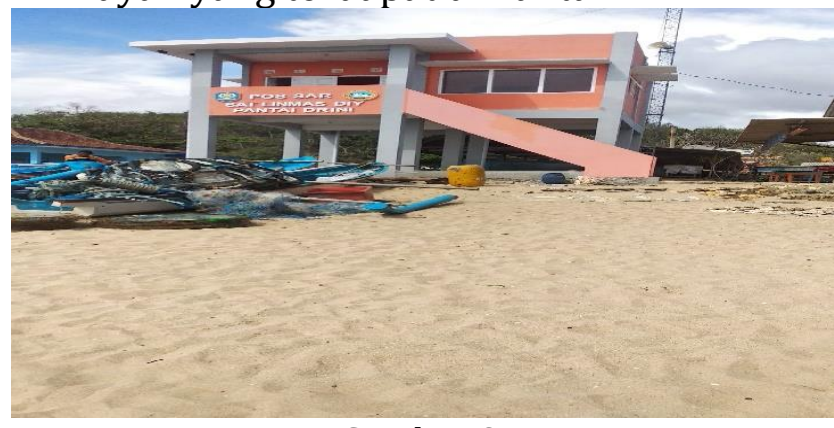

Gambar 8.

Kesiapsiagaan Wilayah Terhadap Bencana di Pantai Drini

Sumber: Data Hasil Penelitian yang Diolah

\section{Perencanaan Pengembangan Pariwisata Tangguh Bencana}

Perencanaan pengembangan pariwisata tangguh bencana meliputi analisis kelebihan dan kekurangan dari suatu destinasi wisata berdasarkan sudut pandang komponen 6A yang berkaitan dengan bencana dan analisis kerentanan wilayah. Hal tersebut digunakan sebagai dasar perencanaan dalam mengembangkan pariwisata tangguh bencana. Salah satu komponen 6A yang berkaitan dengan bencana yaitu ancillary services.

Ancillary services yang terdapat di Pantai Drini dapat dikatakan masih memiliki banyak kekurangan, seperti tidak adanya rumah sakit, puskesmas/klinik/praktik dokter, dan apotek yang memiliki fungsi jika terdapat bencana upaya pertama yang dapat dilakukan adalah mengevakuasi korban ke 
perawatan medis terdekat. Kemudian, berkaitan dengan analisis kerentanan wilayah, kelengkapan pada tanda evakuasi dapat dikatakan masih kurang, seperti tidak adanya peringatan/rambu/tanda jalur evakuasi, jalur evakuasi, titik kumpul, dan early warning system.

Dalam merencanakan pengembangan pariwisata tangguh bencana, semua komponen di atas tersebut setidaknya tersedia pada suatu destinasi wisata. Hal tersebut bertujuan untuk menciptakan iklim wisata yang ramah dan tangguh terhadap bencana. Dapat diketahui bahwa industri pariwisata adalah industri yang memiliki nilai tinggi, jika suatu destinasi wisata memiliki citra yang buruk akibat dari tingginya risiko terhadap bencana dan rendahnya kesiapsiagaan dalam menghadapi bencana, maka industri pariwisata tersebut juga akan terpengaruh. Berikut diagram alir perencanaan pengembangan untuk mewujudkan pariwisata tangguh bencana.

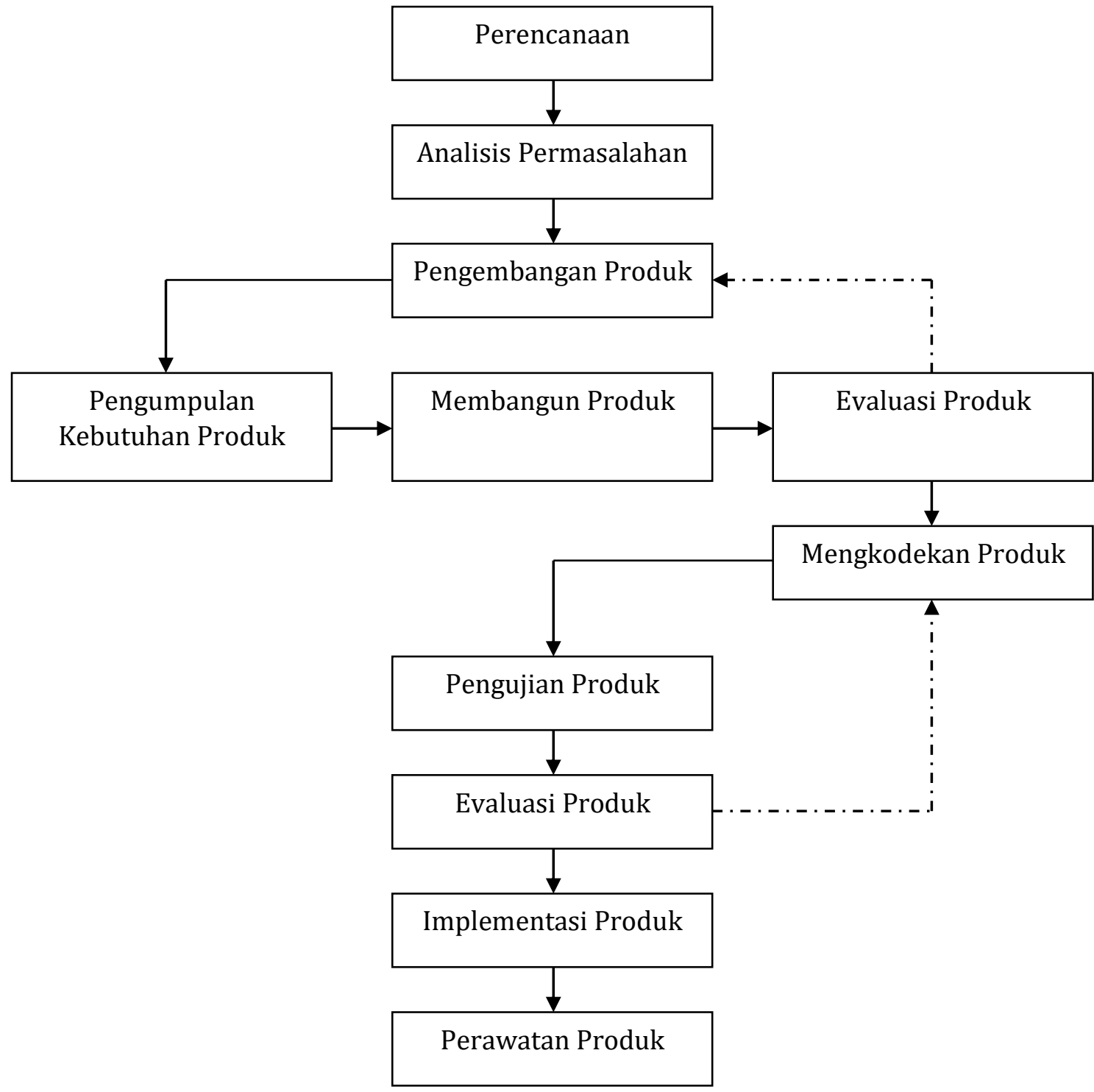

Gambar 9.

Diagram Alir Perencanaan Pengembangan

Sumber: Data Hasil Penelitian yang Diolah 


\section{KESIMPULAN}

Menyadari adanya risiko bencana yang terdapat di Indonesia dan mengancam pariwisata pada wilayah pesisir, perlu adanya mitigasi yang diterapkan untuk meminimalisasi akibat dari terjadinya bencana. Wilayah Kepesisiran Drini yang terdapat di Kabupaten Gunungkidul memiliki potensi wisata yang menarik, namun terdapat juga ancaman yang berupa bencana alam, jika pengelolaan pada pariwisata tersebut tidak optimal, sehingga dapat meningkatkan risiko terjadinya suatu bencana. Adaptasi tersebut dapat dilakukan dengan menganalisis komponen 6A dan analisis kerentanan wilayah, kemudian hasil tersebut digunakan dalam dasar perencanaan pengembangan pariwisata tangguh bencana. Ketersediaan sarana dan prasarana yang terdapat di Wilayah Kepesisiran Drini tergolong masih kurang, seperti tidak adanya rumah sakit, puskesmas/klinik/praktik dokter, dan apotek yang dapat bermanfaat jika terjadi bencana upaya pertolongan pertama dapat mengevakuasi korban di fasilitas kesehatan terdekat. Selain itu, tidak adanya peringatan/rambu/tanda jalur evakuasi, jalur evakuasi, titik kumpul, dan early warning system, mengakibatkan tidak adanya mitigasi struktural yang terdapat di Wilayah Kepesisiran Drini, sehingga perlu adanya mitigasi struktural dengan cara melengkapi semua komponen yang belum tersedia, sehingga risiko dari terjadinya bencana dapat diminimalisasi dan mewujudkan pariwisata tangguh bencana. 


\section{DAFTAR PUSTAKA}

Dahuri, R., Rais, J., Ginting, S. P., \& Sitepu, M. J. 2001. Pengelolaan Sumberdaya Pesisir dan Lautan Secara Terpadu. In Pradnya Paramita. Jakarta.

Damayanti, A., \& Ayuningtyas, R. 2008. Karakteristik Fisik dan Pemanfaatan Pantai Karst Kabupaten Gunungkidul. Makara Journal of Technology, 12(2).

Lasabuda, R. 2013. Pembangunan Wilayah Pesisir dan Lautan dalam Perspektif Negara Kepulauan Republik Indonesia. Jurnal Ilmiah Platax, I, 92-101.

Maghfiroh Asti, K. S. \& H. D. A. 2014. Simulasi Penjalaran dan Prediksi Run-Up Gelombang Tsunami di Pantai Malang. Jurnal Teknik Kelautan, 1, 7-10.

Muljadi, A. J., \& Nurhayati, S. 2002. Pengertian Pariwisata. Kursus Tertulis Pariwisata Tingkat Dasar. Modul I.

Peraturan Menteri Dalam Negeri No. 33 Tahun 2006 tentang Pedoman Umum Mitigasi Bencana

Primadany, S. R. 2013. Analisis Strategi Pengembangan Pariwisata Daerah (Studi pada Dinas Kebudayaan dan Pariwisata Daerah Kabupaten Nganjuk). Jurnal Administrasi Publik, 1(4), 135-143.

Rahman, A. Z. 2015. Kajian Mitigasi Bencana Tanah Longsor di Kabupaten Banjarnegara. Jurnal Manajemen dan Kebijakan Publik, 1(1), 1-14.

Rijanta, R., Hizbaron, D. R., \& Baiquni, M. 2018. Modal Sosial dalam Manajemen Bencana. UGM PRESS.

Undang-undang Nomor 24 Tahun 2007 tentang Penyelenggaraan Penanggulangan Bencana

Westplat, M. J. H., Tondobala, L., \& Makarau, V. H. 2017. Analisis Kerentanan Wilayah Pesisir Pantai di Perkotaan Ternate. SPASIAL, 4(2), 12-18.

Wicaksono, R. D., \& Pangestuti, E. 2019. Analisis Mitigasi Bencana Dalam Meminimalisir Risiko Bencana. Jurnal Administrasi Bisnis (JAB), 71(1), 8-17. 